\title{
Earthquake fault-plane solutions and patterns of seismicity within the Umbria Region, Italy
}

\author{
Maria Grazia Ciaccio $\left({ }^{1}\right)$, Silvia Pondrelli $\left({ }^{2}\right)$ and Alberto Frepoli $\left({ }^{1}\right)$ \\ (1) Istituto Nazionale di Geofisica e Vulcanologia, Roma, Italy \\ ${ }^{(2)}$ Istituto Nazionale di Geofisica e Vulcanologia, Bologna, Italy
}

\begin{abstract}
In this paper we present a review of the seismotectonic features (an analysis of earthquake focal mechanisms and the distribution of seismicity) of the Northern Apennines, Umbria Region (Italy) in the area between Sansepolcro and Norcia. For this analysis, we used Centroid Moment Tensor (CMT) data for earthquakes with magnitude $M>5.0$ and data computed by implementing the standard CMT algorithm to compute Regional Centroid Moment Tensor (RCMT) estimates for moderate-magnitude earthquakes $(4.5<M<5.5)$, integrating pre-existing datasets. We used first-motion polarities to obtain fault-plane solutions for small earthquakes $\left(2.5<M_{d}<4.5\right)$ recorded by the seismic network deployed by the Istituto Nazionale di Geofisica e Vulcanologia. We analyzed the main features of the seismicity and the present-day tectonic regime in order to relate the seismicity patterns to seismogenic structures beneath Central Italy. In particular, we discuss the important role of a major low-angle normal fault, the Altotiberina Fault, in controlling crustal seismicity in this region.
\end{abstract}

Key words fault-plane solution - seismicity - seismotectonic - Italy

\section{Introduction}

The NE-verging Northern Apenninic Orogen is a typical fold and thrust belt. It is dominated by concomitant extension and compression in two adjacent zones: the inner area of the belt, the present study area, and the outer margin of the belt, respectively (Elter et al., 1975; Lavecchia et al., 1987; Frepoli and Amato, 1997; Decandia et al., 1998). Within the inner area, PlioceneQuaternary sedimentation developed in grabens and half-grabens bordered by normal faults. Instrumental seismicity is concentrated in a rela-

Mailing address: Dr. Maria Grazia Ciaccio, Istituto Nazionale di Geofisica e Vulcanologia, Via di Vigna Murata 605, 00143 Roma, Italy; e-mail: ciaccio@ingv.it tively shallow layer that deepens from the internal to external areas (Chiarabba et al., 2005).

The analysis of earthquake fault-plane solutions is a basic tool in understanding the present state of deformation within a region. In this paper we study the seismicity patterns of 79 faultplane solutions determined for earthquakes that occurred in the Umbria Region of the Northern Apennines. As expected, most of the Centroid Moment Tensor (CMT) solutions and most of the focal mechanisms calculated from the firstmotion polarities indicate normal faulting with the exception of one deep earthquake $(41 \mathrm{~km}$ depth) that recorded a thrust-fault focal mechanism. Subcrustal events in the Northern Apennines provide evidence of the presence of a subduction zone (Selvaggi and Amato, 1992; Amato et al., 1997; Chiarabba et al., 2005). This view is supported by tomographic images that depict a high-velocity body extending to $600 \mathrm{~km}$ depth (see Lucente et al., 1999 and references therein) that dips steeply toward the Tyrrhenian Sea. 


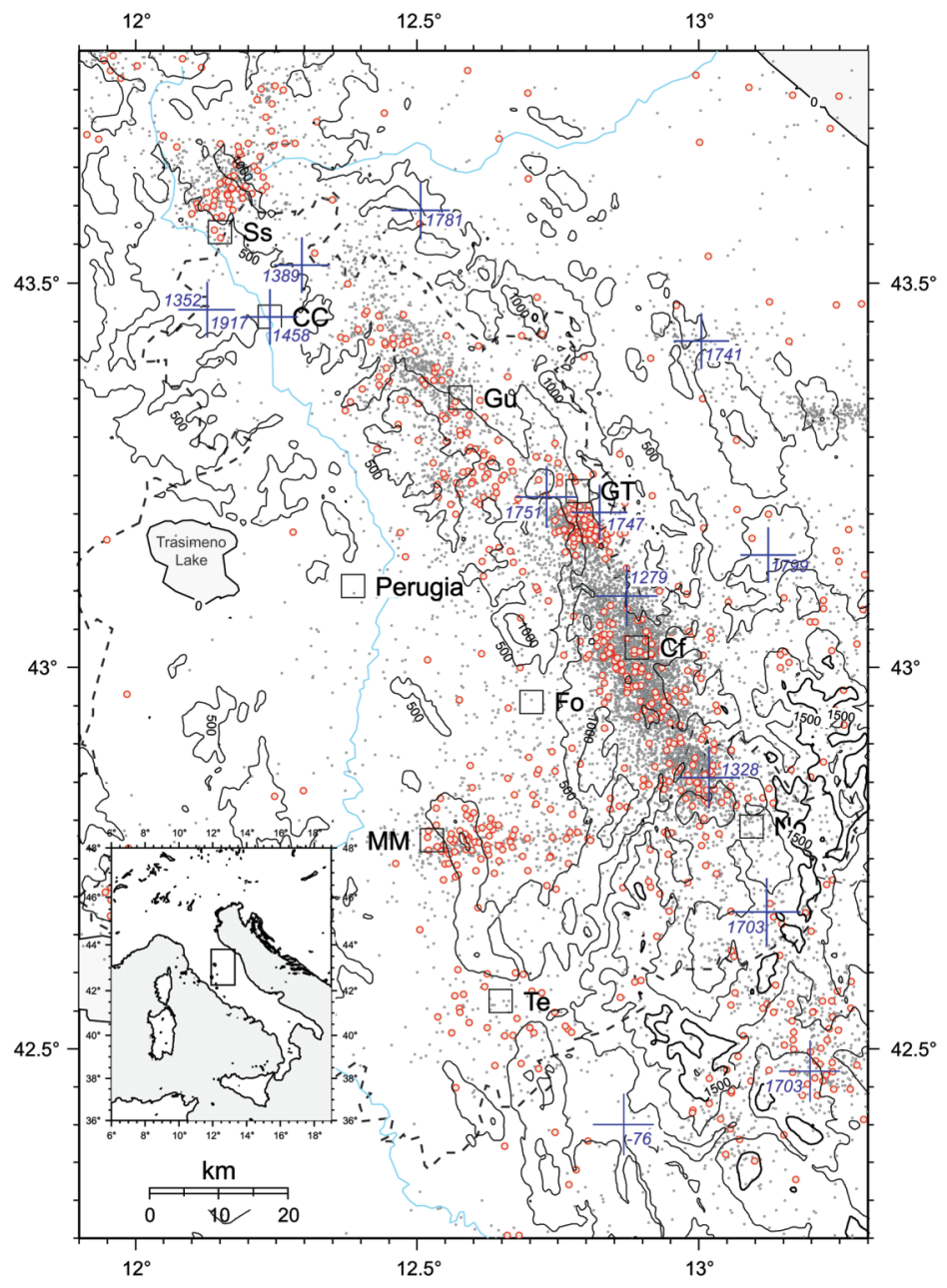

Fig. 1. Seismicity distribution in the study area for the period 1983-2003. Black circles indicate the entire dataset from Databank of INGV; red circles represent the epicenters of events with $M_{d} \geq 3.0$; crosses indicate historical seismicity with intensities $\geq$ IX (CPTI, 1999). Ss - Sansepolcro; CC - Città di Castello; Gu - Gubbio; GT - Gualdo Tadino; Cf - Colfiorito; Fo - Foligno; No - Norcia; Te - Terni. The dotted line represents the border of the Umbrian region. Contour interval is $500 \mathrm{~m}$.

To determine a synoptic picture of the distribution and main features of regional-scale seismicity in this region, we analyzed different seismic sequences that occurred within the area. Seismicity in the Umbria Region is generally investigated from a seismological point of view via the analysis of recent major earthquake sequences. We integrate the results of previous studies with those of the present study, including data for moderate-magnitude events.

\section{Seismotectonic setting}

The Umbria-Marche Apennines are characterised by widespread seismic activity. The dis- 
tribution of epicenters shows a concentration beneath the Apenninic Chain. On the western side of the divide, seismicity is concentrated within the Terni Basin and around the area of Massa Martana, about $50 \mathrm{~km}$ west of the town of Norcia (fig. 1). A small seismic sequence occurred in this area during May-July 1997. Most of the seismic events in this region have a magnitude $M_{d}$ between 2.0 and 3.0 (80\% of events), with only
$2 \%$ of events having $M_{d}>5.0$ (fig. 1). The crustal seismicity data shown in fig. 1 are in large part derived from the 1997 Umbria-Marche (Colfiorito) seismic sequence (Amato et al., 1998). The largest earthquakes in this region occurred in the Colfiorito area (September 1997, $M_{w}$ 6.0), the Gubbio area (April 1984, $M_{w}$ 5.6), and the Norcia area (September 1979, $M_{s}$ 5.9). Other important seismic sequences are characterised by mod-

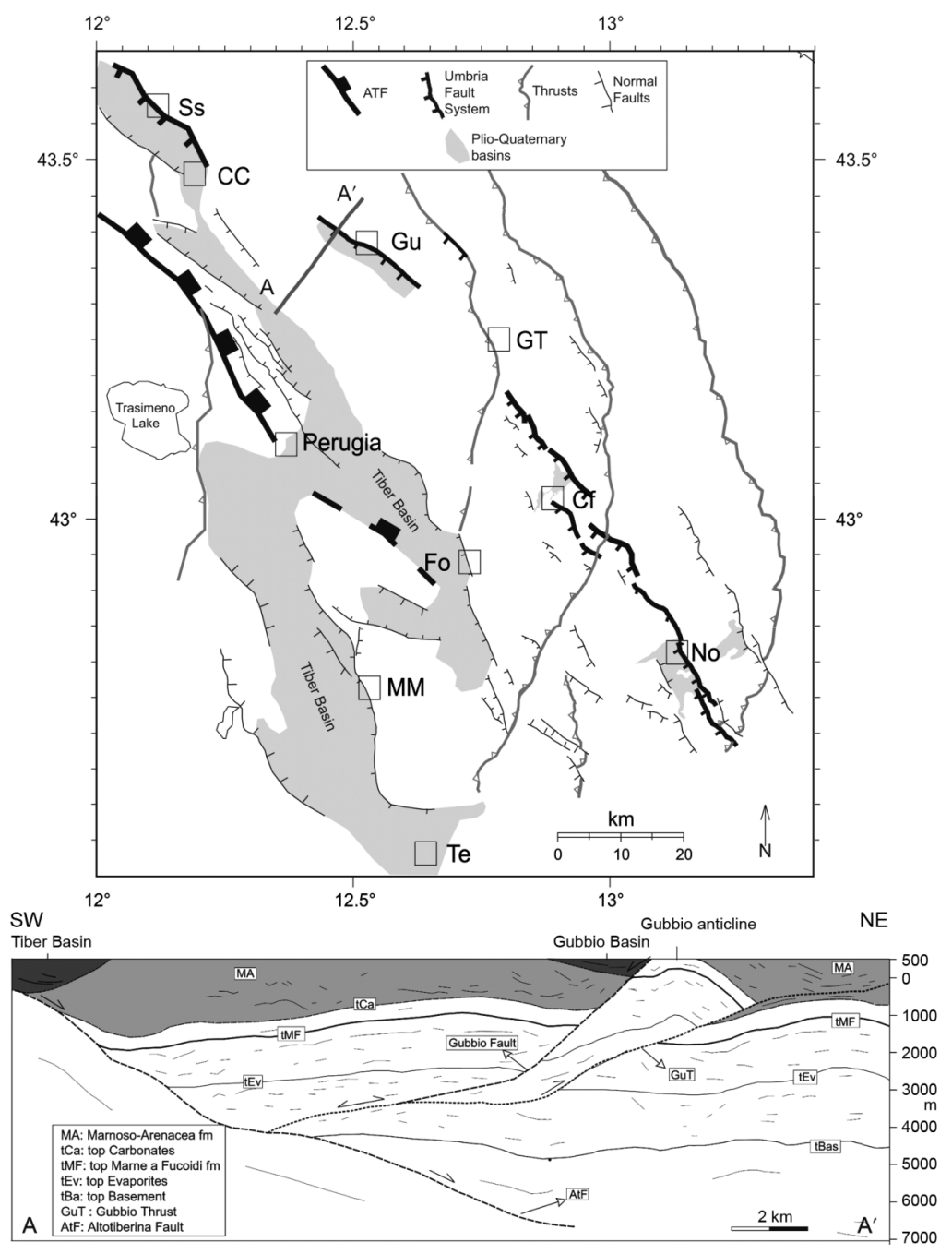

Fig. 2. Schematic structural map of the Umbrian region (modified after Barchi, 2002). The seismic reflection profile (A-A') showing the AtF and the antithetic Gubbio Fault is from Mirabella et al. (2005). 
erate-magnitude mainshocks ranging from $M_{w}$ 4.7 (Sansepolcro, November 2001) to 5.1 (Gualdo Tadino, April 1998).

Several historical earthquakes in this region recorded intensities between IX and XI MCS (Mercalli-Cancani-Sieberg). Among the strongest shocks that occurred in the zone between Gubbio and Sansepolcro are the 1352 Monterchi earthquake, the 1389 Boccaserriola, the 1458 Città di Castello, the 1741 Fabrianese ( $I=\mathrm{IX}, M m=6.0)$, the 1781 Cagliese, and the 1917 Monterchi-Citerna events ( $I=I X-X$, $\mathrm{M} m=6.0$ ) (CPTI Working Group, 2004). In the Gualdo Tadino Zone, large events occurred in 1747 (Fiuminata, $I=I X, M m=6.0$ ) and 1751 $(I=\mathrm{X}, M m=6.6)$. Moving southward, a destructive event occurred in the Norcia area in 1703 ( $I=\mathrm{X}-\mathrm{XI}, M m=7.1$ ) (fig. 1).

Major instrumental earthquakes in this area are related to west-dipping normal faults associated with intramountain basins that represent the surface expression of the extensional strain field. This set of normal faults trends NNW-SSE (fig. 2) from Sansepolcro to Norcia, and is known as the Umbria Fault System (Barchi et al., 2000; Barchi, 2002). A geophysical image of the crustal setting of the Umbria Region derived from the deep seismic reflection profile CROP 03 shows a set of east- and west-dipping normal faults in the upper crust and a thinned and flat- tened lower crust (Barchi et al., 1998). The AtF can be traced to a maximum depth of $5.0 \mathrm{~s}$ TWT (two-way time), i.e. $12-14 \mathrm{~km}$ below the Apennines. The regional E-ENE-dipping low-angle normal fault, the AtF (Barchi et al., 1998; Boncio et al., 1998), is the basal detachment to the SW-dipping normal faults, which are antithetic to the AtF (fig. 2).

\section{Earthquake fault-plane solutions}

\subsection{Moment tensors}

Several moment tensor solutions are available for this region in the Harvard CMT Catalogue (nine events; Dziewonski et al., 2000; http:// www.seismology.harvard.edu/CMTsearch.html; table I and grey focal mechanisms in fig. 3) and in the European-Mediterranean RCMT Catalogue (47 events; Pondrelli et al., 2002, 2004; http://www.ingv.it/seismoglo/RCMT/; table II and fig. 4). The Harvard Catalogue includes all global events since 1977 with a magnitude greater than 5.5, while the RCMT Catalogue includes all moderate-magnitude events of between 4.5 and 5.5 for the Mediterranean region that have occurred since 1997.

The dataset contains few records of moderate-magnitude events prior to 1997. For this

Table I. CMT Catalog. Parameters (strike, dip, and rake of the first and second nodal planes) of moment tensors selected for the study area from the Harvard CMT Catalog (Dziewonski et al., 2001). The label C represents CMT, as described in the text. Events with * represent hypocentral locations sourced from: C1 - Deschamps et al. (1984); C2 - Collettini et al. (2003); C3 - Ciaccio et al. (2005); R1, R2, R4 and R5 - Chiaraluce et al. (2003); R7 and RN1 - Castello et al. (2005); R3 and D2 - present study; F10 - Di Luccio et al. (1998).

\begin{tabular}{lcccccccccccc}
\hline \hline $\begin{array}{c}\text { Date } \\
(\mathrm{d} / \mathrm{m} / \mathrm{yr})\end{array}$ & Lat & Long & $\begin{array}{c}\text { Depth } \\
(\mathrm{km})\end{array}$ & Strike1 & Dip1 & Rake1 & Strike2 & Dip2 & Rake2 & $\begin{array}{c}M_{0} \\
(\mathrm{dyn} \mathrm{cm})\end{array}$ & Exp. & Label \\
\hline $19 / 09 / 1979 *$ & 42.73 & 12.96 & 6.0 & 183 & 28 & -70 & 341 & 64 & -100 & 07.32 & 24 & $\mathrm{C} 1$ \\
$29 / 04 / 1984^{*}$ & 43.27 & 12.57 & 7.0 & 143 & 21 & -72 & 304 & 70 & -97 & 03.36 & 24 & $\mathrm{C} 2$ \\
$26 / 09 / 1997$ & 43.05 & 12.88 & 15.0 & 156 & 38 & -71 & 312 & 54 & -105 & 04.22 & 24 & \\
$26 / 09 / 1997$ & 43.08 & 12.81 & 15.0 & 142 & 39 & -87 & 318 & 51 & -92 & 01.14 & 25 & \\
$03 / 10 / 1997$ & 43.08 & 12.79 & 15.0 & 103 & 42 & -118 & 319 & 54 & -67 & 10.26 & 23 & \\
$06 / 10 / 1997$ & 43.04 & 12.84 & 15.0 & 149 & 23 & -73 & 310 & 68 & -97 & 02.32 & 24 & \\
$12 / 10 / 1997$ & 43.30 & 12.90 & 15.0 & 175 & 45 & -39 & 295 & 63 & -127 & 09.24 & 23 & \\
$26 / 03 / 1998$ & 43.26 & 12.97 & 49.6 & 196 & 23 & -37 & 320 & 76 & -109 & 01.53 & 24 & \\
$03 / 04 / 1998^{*}$ & 43.16 & 12.70 & 6.5 & 152 & 23 & -80 & 321 & 68 & -94 & 06.05 & 23 & $\mathrm{C} 3$ \\
\hline
\end{tabular}




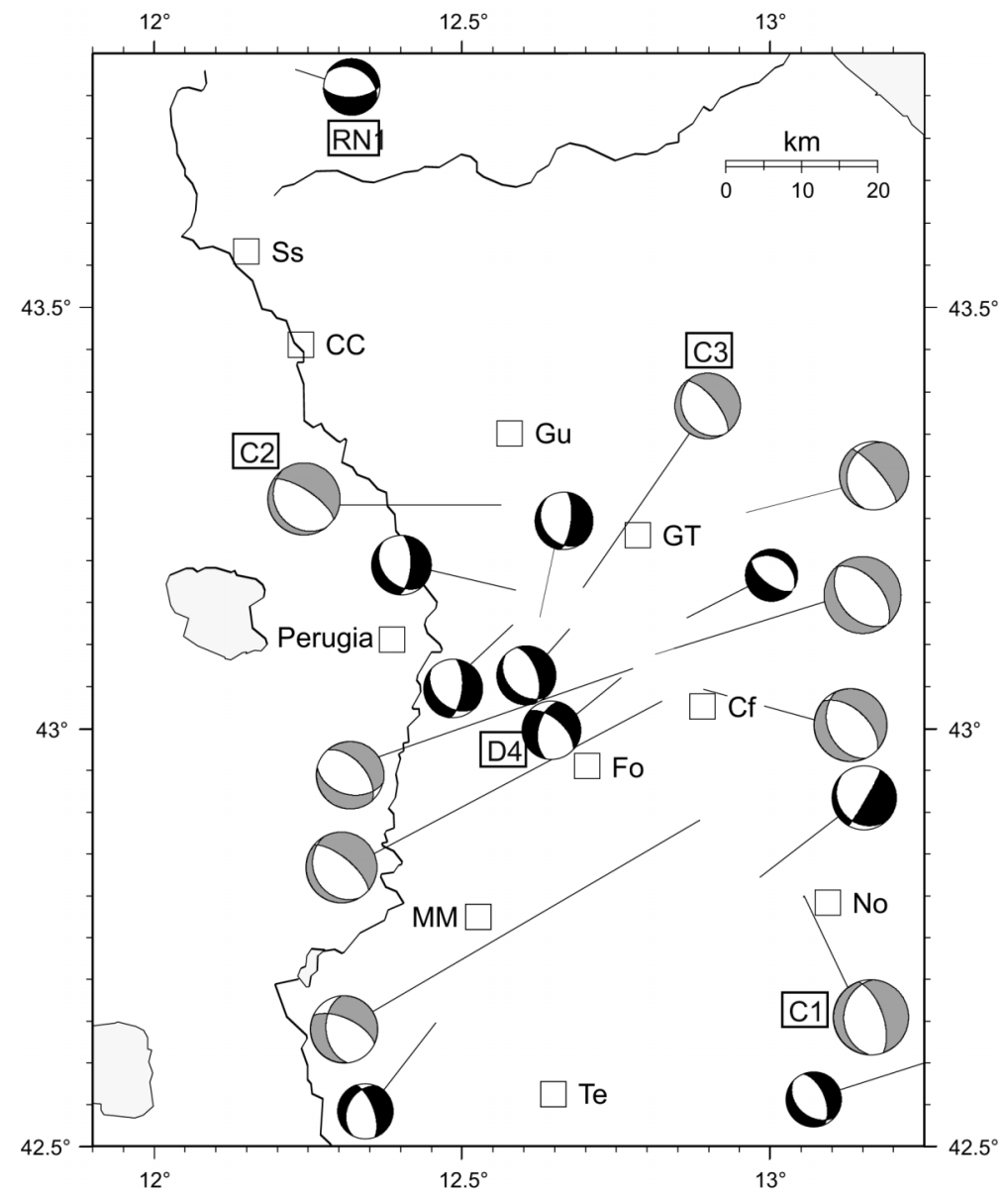

Fig. 3. Map of moment tensors available for the study region. Grey focal mechanisms are from the Harvard CMT Catalog (1977-2000); black focal mechanisms are from the present study.

Table II. RCMT Catalog. Parameters (strike, dip, and rake of the first and second nodal planes) of moment tensors selected for the study area from the Euro-Mediterranean RCMT Catalog (Pondrelli et al., 2002, 2004). The label R represents RCMT, as described in the text; D represents deep. Events with * represent hypocentral locations sourced from: C1 - Deschamps et al. (1984); C2 - Collettini et al. (2003); C3 - Ciaccio et al. (2005); R1, R2, R4 and R5 - Chiaraluce et al. (2003); R7 and RN1 - Castello et al. (2005); R3 and D2 - present study; F10 - Di Luccio et al. (1998).

\begin{tabular}{lcccccccccccc}
\hline $\begin{array}{c}\text { Date } \\
(\mathrm{d} / \mathrm{m} / \mathrm{yr})\end{array}$ & Lat & Long & $\begin{array}{c}\text { Depth } \\
(\mathrm{km})\end{array}$ & Strike1 & Dip1 & Rake1 & Strike2 & Dip2 & Rake2 & $\begin{array}{c}M_{0} \\
(\mathrm{dyn} \mathrm{cm})\end{array}$ & Exp. & Label \\
\hline $26 / 09 / 1997 *$ & 43.02 & 12.89 & 6.7 & 321 & 44 & -98 & 152 & 46 & -83 & 04.04 & 24 & $\mathrm{R} 1$ \\
$26 / 09 / 1997 *$ & 43.03 & 12.85 & 6.3 & 144 & 42 & -80 & 312 & 49 & -98 & 01.18 & 25 & $\mathrm{R} 2$ \\
$26 / 09 / 1997$ & 43.01 & 12.97 & 10.0 & 147 & 29 & -88 & 325 & 61 & -91 & 07.30 & 22 & \\
$26 / 09 / 1997$ & 43.06 & 12.85 & 10.0 & 193 & 45 & -43 & 316 & 61 & -126 & 04.06 & 22 & \\
\hline
\end{tabular}


Table II (continued).

\begin{tabular}{|c|c|c|c|c|c|c|c|c|c|c|c|c|}
\hline $\begin{array}{c}\text { Date } \\
(\mathrm{d} / \mathrm{m} / \mathrm{yr})\end{array}$ & Lat & Long & $\begin{array}{c}\text { Depth } \\
(\mathrm{km})\end{array}$ & Strike1 & Dip1 & Rake1 & Strike2 & Dip2 & Rake2 & $\begin{array}{c}M_{0} \\
(\text { dyn } \mathrm{cm})\end{array}$ & Exp. & Label \\
\hline 27/09/1997 & 43.09 & 12.81 & 10.0 & 326 & 35 & -92 & 148 & 55 & -89 & 04.15 & 22 & \\
\hline 27/09/1997 & 43.02 & 12.83 & 10.0 & 288 & 36 & -135 & 160 & 66 & -63 & 02.26 & 22 & \\
\hline 27/09/1997 & 43.06 & 12.77 & 10.0 & 136 & 35 & -80 & 304 & 56 & -97 & 04.08 & 22 & \\
\hline 02/10/1997* & 43.61 & 12.15 & 15.1 & 158 & 41 & -58 & 298 & 56 & -115 & 05.36 & 22 & R3 \\
\hline 03/10/1997 & 43.03 & 12.84 & 10.0 & 141 & 43 & -74 & 300 & 49 & -104 & 09.05 & 23 & \\
\hline 04/10/1997 & 42.90 & 12.90 & 10.0 & 299 & 42 & -101 & 133 & 49 & -81 & 05.08 & 22 & \\
\hline 04/10/1997 & 42.93 & 12.86 & 10.0 & 322 & 33 & -52 & 99 & 64 & -112 & 05.39 & 22 & \\
\hline 04/10/1997 & 42.94 & 12.93 & 10.0 & 318 & 42 & -80 & 125 & 49 & -99 & 01.24 & 23 & \\
\hline 04/10/1997 & 42.93 & 12.90 & 10.0 & 329 & 43 & -77 & 131 & 48 & -102 & 05.12 & 22 & \\
\hline 06/10/1997* & 43.02 & 12.84 & 5.5 & 145 & 40 & -80 & 312 & 51 & -98 & 02.14 & 24 & $\mathrm{R} 4$ \\
\hline 07/10/1997 & 42.99 & 12.82 & 10.0 & 126 & 26 & -102 & 319 & 65 & -84 & 02.29 & 22 & \\
\hline 07/10/1997 & 43.03 & 12.85 & 10.0 & 141 & 42 & -77 & 304 & 49 & -101 & 07.14 & 22 & \\
\hline 12/10/1997 & 42.91 & 12.94 & 12.0 & 321 & 40 & -100 & 154 & 51 & -82 & 08.19 & 23 & \\
\hline 12/10/1997 & 42.86 & 12.97 & 10.0 & 271 & 14 & -133 & 136 & 80 & -80 & 04.02 & 22 & \\
\hline 13/10/1997 & 42.90 & 13.00 & 10.0 & 315 & 37 & -73 & 115 & 54 & -102 & 04.29 & 22 & \\
\hline 13/10/1997 & 42.89 & 12.92 & 10.0 & 305 & 35 & -96 & 133 & 56 & -86 & 04.37 & 22 & \\
\hline 14/10/1997* & 42.93 & 12.92 & 5.2 & 122 & 38 & -100 & 314 & 52 & -82 & 03.39 & 24 & R5 \\
\hline 15/10/1997 & 42.93 & 12.89 & 10.0 & 329 & 40 & -65 & 117 & 55 & -110 & 04.44 & 22 & \\
\hline 16/10/1997 & 42.91 & 12.92 & 10.0 & 310 & 11 & -80 & 120 & 79 & -92 & 04.04 & 22 & \\
\hline 16/10/1997 & 42.98 & 12.89 & 10.0 & 118 & 35 & -88 & 295 & 55 & -92 & 01.50 & 22 & \\
\hline 16/10/1997 & 43.04 & 12.89 & 12.0 & 287 & 80 & 175 & 18 & 85 & 10 & 04.29 & 22 & R6 \\
\hline 16/10/1997 & 42.88 & 12.97 & 10.0 & 305 & 33 & -123 & 163 & 63 & -70 & 03.08 & 22 & \\
\hline 17/10/1997 & 42.89 & 12.91 & 10.0 & 326 & 48 & -53 & 97 & 54 & -124 & 03.23 & 22 & \\
\hline 19/10/1997 & 42.97 & 12.79 & 10.0 & 128 & 44 & -103 & 326 & 47 & -78 & 03.20 & 22 & \\
\hline 25/10/1997 & 42.84 & 13.01 & 10.0 & 333 & 33 & -54 & 112 & 64 & -111 & 03.22 & 22 & \\
\hline 09/11/1997 & 42.87 & 13.00 & 12.0 & 118 & 46 & -113 & 329 & 48 & -68 & 02.53 & 23 & \\
\hline 30/11/1997 & 42.88 & 12.95 & 10.0 & 125 & 36 & -119 & 339 & 59 & -70 & 04.07 & 22 & \\
\hline $31 / 12 / 1997$ & 42.87 & 12.99 & 10.0 & 293 & 35 & -135 & 164 & 66 & -64 & 03.57 & 22 & \\
\hline 07/02/1998 & 43.00 & 12.90 & 10.0 & 308 & 36 & -98 & 138 & 55 & -84 & 05.11 & 22 & \\
\hline 21/03/1998 & 42.90 & 12.90 & 10.0 & 137 & 15 & -97 & 325 & 75 & -88 & 04.01 & 23 & \\
\hline 26/03/1998 & 43.19 & 12.84 & 51.5 & 204 & 36 & -17 & 308 & 80 & -125 & 10.27 & 23 & D1 \\
\hline 03/04/1998 & 43.16 & 12.70 & 10.0 & 142 & 30 & -106 & 341 & 61 & -81 & 06.07 & 23 & \\
\hline 03/04/1998 & 43.23 & 12.67 & 10.0 & 152 & 33 & -108 & 352 & 59 & -79 & 03.29 & 22 & \\
\hline 05/04/1998 & 43.18 & 12.76 & 10.0 & 138 & 31 & -98 & 327 & 59 & -85 & 02.25 & 23 & \\
\hline 02/06/1998 & 43.17 & 12.73 & 10.0 & 311 & 42 & -124 & 173 & 56 & -63 & 03.03 & 22 & \\
\hline 25/06/1998 & 43.00 & 12.80 & 10.0 & 96 & 47 & -123 & 319 & 52 & -60 & 01.16 & 22 & \\
\hline 10/10/1999 & 42.67 & 13.19 & 10.0 & 348 & 50 & -47 & 112 & 55 & -129 & 03.01 & 22 & \\
\hline 01/04/2000 & 42.89 & 11.74 & 10.0 & 309 & 38 & -49 & 81 & 63 & -117 & 08.03 & 22 & \\
\hline $22 / 06 / 2000^{*}$ & 43.30 & 12.48 & 34.4 & 233 & 2 & 1 & 141 & 90 & 92 & 09.23 & 22 & D2 \\
\hline 02/09/2000 & 43.26 & 12.99 & 41.2 & 325 & 40 & 82 & 156 & 51 & 97 & 05.51 & 22 & D3 \\
\hline $16 / 12 / 2000$ & 42.65 & 12.66 & 10.0 & 273 & 35 & -76 & 76 & 56 & -100 & 03.08 & 22 & \\
\hline 26/11/2001* & 43.60 & 12.11 & 5.5 & 358 & 21 & -72 & 158 & 70 & -97 & 01.38 & 23 & R7 \\
\hline $21 / 02 / 2002$ & 43.76 & 12.05 & 10.0 & 313 & 35 & -86 & 128 & 55 & -93 & 02.10 & 22 & \\
\hline
\end{tabular}




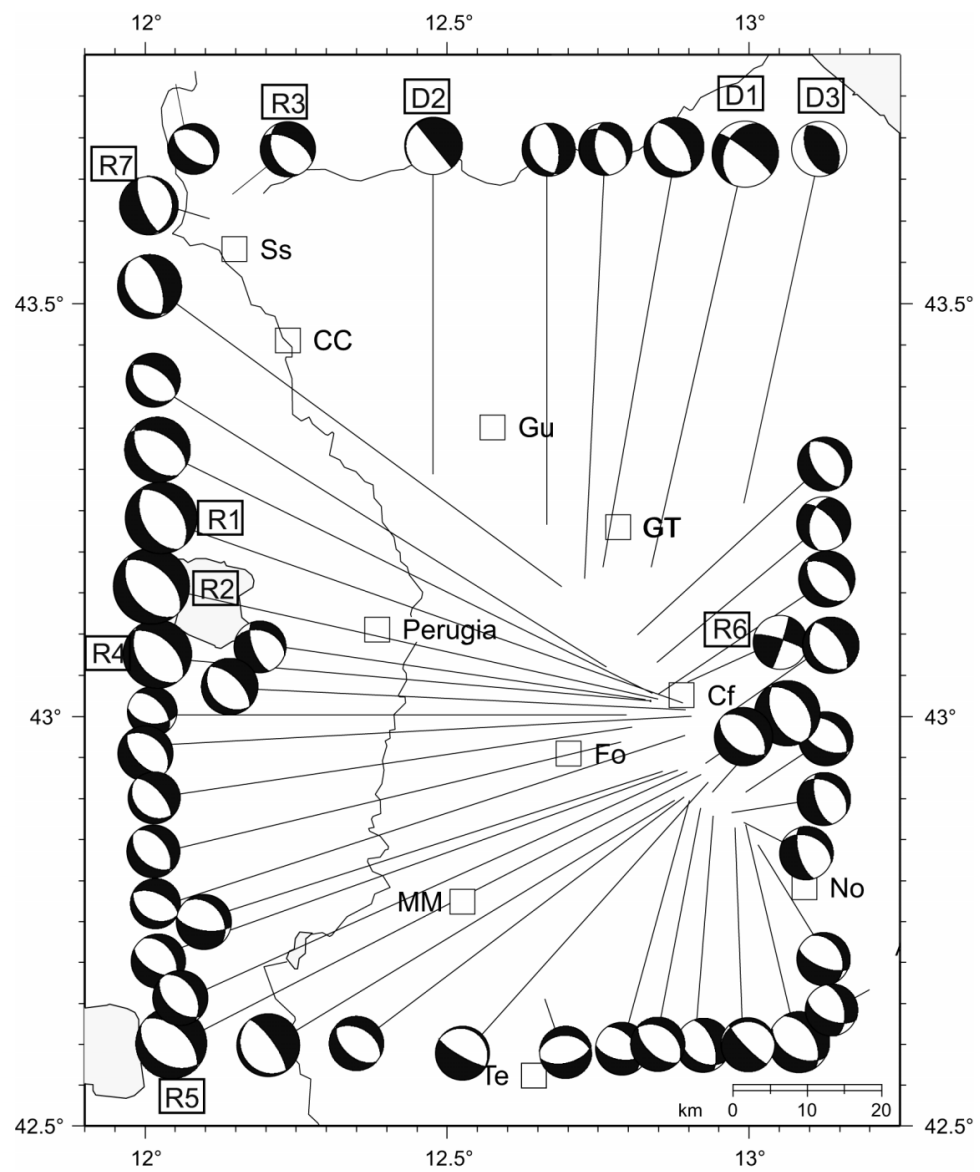

Fig. 4. Map of moment tensors available for the study region from the European-Mediterranean RCMT Cata$\log (1997-2000)$.

Table III. RCMT New. Parameters (strike, dip, and rake of the first and second nodal planes) of moment tensors obtained during the present study. The label RN represents RCMT, as described in the text. Events with * represent hypocentral locations sourced from: C1 - Deschamps et al. (1984); C2 - Collettini et al. (2003); C3 Ciaccio et al. (2005); R1, R2, R4 and R5 - Chiaraluce et al. (2003); R7 and RN1 - Castello et al. (2005); R3 and D2 - present study; F10 - Di Luccio et al. (1998).

\begin{tabular}{lcccccccccccc}
\hline $\begin{array}{c}\text { Date } \\
(\mathrm{d} / \mathrm{m} / \mathrm{yr})\end{array}$ & Lat & Long & $\begin{array}{c}\text { Depth } \\
(\mathrm{km})\end{array}$ & Strike1 & Dip1 & Rake1 & Strike2 & Dip2 & Rake2 $\begin{array}{c}M_{0} \\
(\mathrm{dyn} \mathrm{cm})\end{array}$ & Exp. & Label \\
\hline $28 / 02 / 1980$ & 42.82 & 12.99 & 15.0 & 134 & 20 & -165 & 30 & 85 & -70 & 03.87 & 23 & \\
$21 / 05 / 1979$ & 43.13 & 12.86 & 10.0 & 299 & 30 & -98 & 128 & 61 & -85 & 02.38 & 22 & \\
$05 / 06 / 1993$ & 43.12 & 12.68 & 10.0 & 135 & 33 & -112 & 342 & 59 & -76 & 01.15 & 23 & \\
$05 / 07 / 1987 *$ & 43.76 & 12.21 & 15.5 & 300 & 34 & -63 & 88 & 60 & -107 & 06.14 & 22 & RN1 \\
$30 / 07 / 1978$ & 42.65 & 12.46 & 10.0 & 206 & 35 & -49 & 340 & 65 & -114 & 05.02 & 22 & \\
$17 / 10 / 1982$ & 43.12 & 12.59 & 13.0 & 132 & 38 & -137 & 6 & 65 & -60 & 01.08 & 23 & \\
\hline
\end{tabular}


Table III (continued).

\begin{tabular}{ccccccccccccc}
\hline \hline $\begin{array}{c}\text { Date } \\
(\mathrm{d} / \mathrm{m} / \mathrm{yr})\end{array}$ & Lat & Long & $\begin{array}{c}\text { Depth } \\
(\mathrm{km})\end{array}$ & Strike1 & Dip1 & Rake1 & Strike2 & Dip2 & Rake2 & $\begin{array}{c}M_{0} \\
(\mathrm{dyn} \mathrm{cm})\end{array}$ & Exp. & Label \\
\hline $17 / 10 / 1982$ & 43.16 & 12.59 & 17.2 & 139 & 34 & -129 & 3 & 65 & -67 & 01.17 & 23 & \\
$18 / 10 / 1982$ & 43.13 & 12.63 & 15.0 & 142 & 27 & -131 & 7 & 70 & -72 & 08.49 & 22 & \\
$20 / 10 / 1996$ & 42.60 & 13.28 & 10.0 & 130 & 37 & -113 & 338 & 57 & -74 & 04.20 & 22 & \\
$22 / 12 / 1989$ & 43.06 & 12.76 & 36.8 & 192 & 51 & -43 & 312 & 58 & -132 & 09.11 & 22 & D4 \\
\hline
\end{tabular}

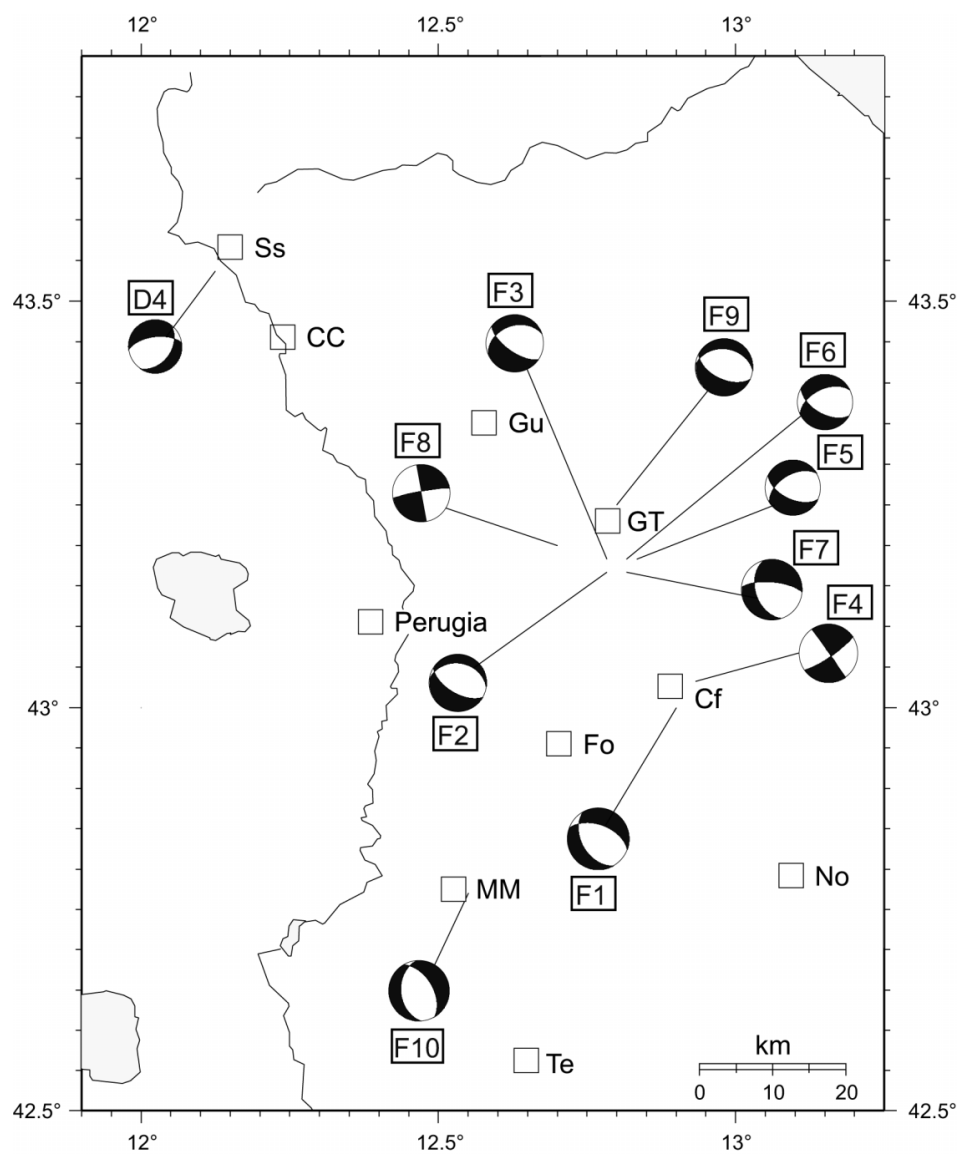

Fig. 5. Map of focal mechanisms obtained from first-motion polarities solutions.

reason, we selected all earthquakes from the NEIS Catalogue with magnitudes between 4.5 and 5.5 that occurred in the study region between 1977 (start of the digital era) and 1997. We excluded from analysis all those events for which a moment tensor solution was already available. We then computed the moment tensors for 10 events (table III; black focal mechanisms in fig. 3). Most of these show normalfaulting focal mechanisms, while those that 
show a different solution, from thrust to strikeslip, are associated with deeper events such as the one that occurred on September 2, 2000 at a depth in excess of $40 \mathrm{~km}$ (D3 in fig. 4; see parameters in table II). The only shallow event with a moment tensor solution other than normal faulting occurred during the Colfiorito seismic sequence (see R6 in fig. 4); Chiaraluce et al. (2004), Nostro et al. (2005), and Collettini et al. (2005) associated this event with fault reactivation. Hence, the moment tensor dataset is characterized by a strong homogeneity.

\subsection{First-motion polarity solutions}

In this study, we analyzed 62 small- to moderate-magnitude earthquakes $\left(2.5<M_{d}<4.5\right)$ that occurred in the study region during the period 1996-2001. Arrival times and polarities were accurately re-picked from digital seismic waveforms recorded by the INGV seismic network. Earthquakes were located using the Hypoinverse code (Klein, 1989) and the gradient velocity structure of Frepoli and Amato (1997). Earthquakes of the 1997 Colfiorito seismic sequence (from September 26 to November 3) with a magnitude greater than 3.0 are not included in this analysis because they have been already analyzed by Amato et al. (1998) and Chiaraluce et al. (2003, 2004). All new locations show crustal depths ranging from 2 to 12 $\mathrm{km}$ : only four earthquakes are located at intermediate depths between 34 and $54 \mathrm{~km}$. From this dataset we selected 12 fault-plane solutions (fig. 5; see parameters in table IV) on the basis of the two output quality factors $Q f$ and $Q p$ of the FPFIT code (Reasenberg and Oppenheimer, 1985): both factors range from A to $C$ with decreasing quality (table V). $Q f$ reflects the misfit in solution prediction $F j$ of the polarity data, while $Q p$ reflects the solution uniqueness in terms of $90 \%$ confidence regions of the strike, dip, and rake of the fault plane. Those faultplane solutions for which one or both quality factors equalled $\mathrm{C}$ were rejected.

Plunges of $P$ - and $T$-axes are used to divide focal mechanism datasets into the main stress regime categories (Zoback, 1992; see table VI). Following this subdivision, 10 fault-plane solutions of our dataset show a large normal-fault component (NF and NS categories), while 2 are pure strike-slip solutions (SS category; see table IV).

Table IV. First Motion Polarities. Hypocentral parameters; magnitudes (code magnitude $M_{d}$ and Richter magnitude $M_{l}$ ); location errors; strike, dip, and rake of the first nodal plane dipping to the east clockwise from north; number of polarities; quality factors; and fault-plane solution categories for the 11 selected focal mechanisms determined using the first polarities method. Solution number 10 represents a subcrustal earthquake. The label $F$ represents first-motion polarities. Events with * represent hypocentral locations sourced from: C1 - Deschamps et al. (1984); C2 - Collettini et al. (2003); C3 - Ciaccio et al. (2005); R1, R2, R4 and R5 - Chiaraluce et al. (2003); R7 and RN1 - Castello et al. (2005); R3 and D2 - present study; F10 - Di Luccio et al. (1998).

\begin{tabular}{lcccccccccccccc}
\hline \hline $\begin{array}{c}\text { Date } \\
(\mathrm{d} / \mathrm{m} / \mathrm{yr})\end{array}$ & Lat & Long & $\begin{array}{c}\text { Depth } \\
(\mathrm{km})\end{array}$ & Strike & Dip & Rake & erz & erh & Pol. & Qf & $Q p$ & $M_{d}$ & FPS Cat. Label \\
\hline $29 / 11 / 1997$ & 43.03 & 12.93 & 5.9 & 150 & 45 & -60 & 2.2 & 1.6 & 10 & $\mathrm{~A}$ & $\mathrm{~A}$ & 3.8 & $\mathrm{NF}$ & $\mathrm{F} 1$ \\
$11 / 12 / 1997$ & 43.17 & 12.78 & 3.6 & 120 & 60 & -80 & 1.0 & 0.8 & 9 & $\mathrm{~A}$ & $\mathrm{~A}$ & 3.5 & $\mathrm{NF}$ & $\mathrm{F} 2$ \\
$23 / 04 / 1998$ & 43.18 & 12.78 & 6.9 & 125 & 65 & -60 & 2.0 & 1.2 & 7 & $\mathrm{~A}$ & $\mathrm{~A}$ & 3.5 & $\mathrm{NF}$ & $\mathrm{F} 3$ \\
$21 / 05 / 1998$ & 4300 & 12.90 & 2.4 & 325 & 90 & -10 & 2.7 & 1.5 & 9 & $\mathrm{~A}$ & $\mathrm{~B}$ & 3.6 & $\mathrm{SS}$ & $\mathrm{F} 4$ \\
$01 / 06 / 1998$ & 43.18 & 12.83 & 5.6 & 115 & 55 & -50 & 2.4 & 1.4 & 7 & $\mathrm{~A}$ & $\mathrm{~A}$ & 3.4 & $\mathrm{NF}$ & $\mathrm{F} 5$ \\
$04 / 06 / 1998$ & 43.18 & 12.82 & 7.2 & 120 & 55 & -50 & 2.1 & 1.3 & 8 & $\mathrm{~A}$ & $\mathrm{~A}$ & 3.4 & $\mathrm{NF}$ & $\mathrm{F} 6$ \\
$11 / 08 / 1998$ & 43.17 & 12.82 & 6.6 & 275 & 70 & -130 & 2.1 & 1.4 & 9 & $\mathrm{~B}$ & $\mathrm{~A}$ & 3.7 & $\mathrm{NF}$ & $\mathrm{F} 7$ \\
$31 / 08 / 1998$ & 43.2 & 12.70 & 7.9 & 260 & 85 & 180 & 2.1 & 1.4 & 6 & $\mathrm{~A}$ & $\mathrm{~B}$ & 3.5 & $\mathrm{SS}$ & $\mathrm{F} 8$ \\
$11 / 08 / 2000$ & 43.25 & 12.80 & 7.9 & 115 & 55 & -80 & 2.2 & 1.3 & 7 & $\mathrm{~A}$ & $\mathrm{~A}$ & 3.5 & $\mathrm{NF}$ & $\mathrm{F} 9$ \\
$29 / 04 / 2001$ & 43.53 & 12.12 & 54.2 & 35 & 40 & -130 & 4.7 & 1.3 & 16 & $\mathrm{~A}$ & $\mathrm{~A}$ & 3.3 & $\mathrm{NF}$ & $\mathrm{D} 5$ \\
$12 / 05 / 1997 *$ & 42.77 & 12.55 & 6.0 & 175 & 40 & -170 & 3.6 & 1.4 & 20 & $A$ & $A$ & $4.5 M_{l}$ & $N F$ & $F 10$ \\
\hline
\end{tabular}


Table V. Fault-plane solution quality factors $Q f$ and $Q p . F j$ is the solution prediction misfit to the polarity data. Dstr, Ddip, and Drake represent ranges in the variability of strike, dip, and rake, respectively.

\begin{tabular}{cccc}
\hline \hline & $Q f$ & & $Q p$ \\
\hline A & $F j \leq 0.025$ & A & Dstr, Ddip, Drake $\leq 20^{\circ}$ \\
B & $0.025<F j \leq 0.1$ & B & $20^{\circ}$ to $40^{\circ}$ \\
C & $F j>0.1$ & C & $>40^{\circ}$ \\
\hline
\end{tabular}

Table VI. Fault-plane solution categories based on different plunge ranges for $P$ - and $T$-axes for the WSM, as determined according to Zoback (1992).

\begin{tabular}{ccc}
\hline \hline$P$ & $T$ & FPS categories \\
\hline$p l \geq 52^{\circ}$ & $p l \leq 35^{\circ}$ & $\mathrm{NF}$ \\
$40^{\circ} \leq p l<52^{\circ}$ & $p l \leq 20^{\circ}$ & $\mathrm{NS}$ \\
$p l<40^{\circ}$ & $p l \leq 20^{\circ}$ & $\mathrm{SS}$ \\
$p l \leq 20^{\circ}$ & $p l<40^{\circ}$ & $\mathrm{SS}$ \\
$p l \leq 20^{\circ}$ & $40^{\circ} \leq p l<52^{\circ}$ & $\mathrm{TS}$ \\
$p l \leq 35^{\circ}$ & $p l \geq 52^{\circ}$ & $\mathrm{TF}$ \\
\hline
\end{tabular}

\section{Seismic sequences of the study area: a review}

We now analyze, from north to south, the main sequences that have occurred in the study area and that have been recorded by permanent seismic stations of the Rete Sismica Nazionale Centralizzata (RSNC) of the INGV, as well as local temporary seismic networks (data of the Sansepolcro sequences from Castello et al., 2005; data of the Gubbio sequence from Haessler et al., 1988 and Collettini et al., 2003; data of the Gualdo Tadino sequence from Ciaccio et al., 2005; data of the Colfiorito sequence from Chiaraluce et al., 2003; data of the Norcia sequence from Chiarabba, pers. comm.). To gain a complete picture of the instrumental seismicity of the area, we also consider minor sequences that have not been studied previously (Massa Martana in 1997; Sansepolcro in 1997 and 2001; Umbertide in 2000). These data show strong and highly continuous occurrences of earthquakes throughout the entire region. The geometry of the fault zones is imaged from the distribution of hypocenters that developed during aftershock sequences and from mainshock fault-plane solutions. This represents a useful tool in modeling seismicity patterns. The faultplane solutions for the larger and smaller earthquakes for which digital data are available indicate that the current tectonics of the area is mainly driven by an extensional regime with an approximately horizontal $\sigma_{3}$ and vertical $\sigma_{1}$.

\subsection{The Sansepolcro sequences}

The area north of Sansepolcro City has been struck in recent years by moderate-magnitude earthquakes and diffuse seismicity: four sequences occurred between 1987 and 2001. The strongest mainshock $\left(M_{w}=4.7 ; M_{l}=4.3\right)$ occurred on November 26, 2001 (focal mechanism $\mathrm{R} 7$ in fig. 4; parameters in table II; $T$-axis azimuth $254^{\circ}$ ), followed by a seismic sequence of about 150 events recorded by the RSNC (section A in fig. 6). The other sequences had mainshocks of $M_{w}=4.4\left(M_{l}=4.3\right)$ in October 1997 (section B in fig. 6; R3 in fig. 4; parameters in table II; $T$-axis azimuth $45^{\circ}$ ), $M_{l}=3.0$ in May 1990, and $M_{l}=3.7$ in July 1987 (RN1 in fig. 3, parameters in table III, $T$-axis azimuth $190^{\circ}$ ). The depth of the 2001 mainshock, obtained from re-picking of the waveforms recorded by the RSNC and local networks, is localised at $5.5 \mathrm{~km}$ depth. The mainshock displays a normal-fault mechanism with a NW-SE strike and a low-angle rupture plane $\left(21^{\circ}\right)$ dipping to the NE, similar to the focal mechanism of the 1997 sequence. The hypocenters of the 1997 sequence have large location errors because few seismic stations recorded the events; in any case, it is possible to observe a SW-dipping alignment in section B. The focal sphere of the 1987 mainshock shows a normal mechanism with an E-W strike.

\subsection{The Umbertide sequence}

On June 22, 2000, following a $M_{w} 4.6$ earthquake, a seismic sequence began in an area close to Umbertide. This sequence shows a pe- 


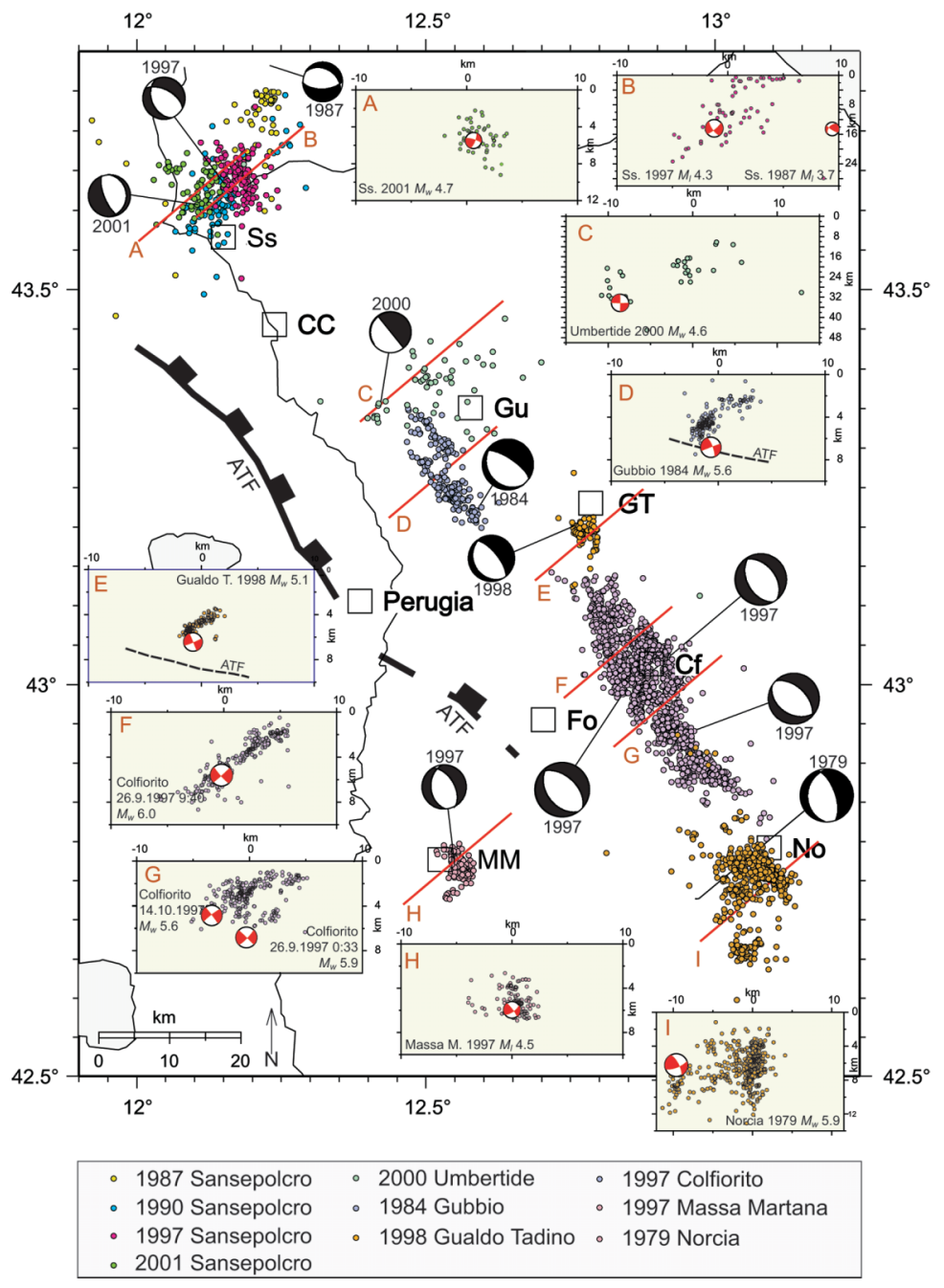

Fig. 6. Epicenters of the main seismic sequences that have occurred in the study area, including hypocenter sections and focal mechanisms of the mainshocks as described in the text (Di Luccio et al., 1998; Chiaraluce et al., 2003; Collettini et al., 2003; Castello et al., 2005; Ciaccio et al., 2005). Note that the vertical scales on the seismic sections vary for different hypocentral depths.

culiar pattern that is different from that of the other sequences of the area. The mainshock solution (D2 in fig. 4; parameters in table II) belongs to the 'unknown' stress-field category, with both $P$ - and $T$-axes plunging at approximately $45^{\circ}$ (Zoback, 1992). Our location (Hypoinverse code, Klein, 1989) indicates the hypo- center at $34.4 \mathrm{~km}$ depth. Picking of the aftershock waveforms, 60 nearby events, and the resulting locations show deep hypocenters, located between 12 and $40 \mathrm{~km}$ depth. Section $\mathrm{C}$ in fig. 6 does not show a clear and unique fault plane, even though the distribution of events appears to define a SW-dipping plane. 


\subsection{The Gubbio sequence}

On April 29, 1984, a seismic sequence occurred in the area of Gubbio. The sequence began with a $M_{w} 5.6$ mainshock showing a focal mechanism with almost pure normal faulting and a small left-lateral shear component and nodal planes oriented along the Apenninic direction (focal mechanism $\mathrm{C} 2$ in fig. 3; parameters in table I; $T$-axis azimuth $89^{\circ}$ ). The distribution of aftershocks is concentrated in two parallel clusters that trend in the Apenninic direction. In a cross-section oriented perpendicular to the strike of the fault, seismicity data indicate a fault plane that dips gently to the SW; hypocenters range between 1 and $7 \mathrm{~km}$ depth (section D in fig. 6). The mainshock is located at a depth of $7 \mathrm{~km}$, close to the intersection between the SW-dipping normal faults and the AtF at the base of the seismogenic block (Haessler et al., 1988; Collettini et al., 2003).

The fault geometry is well depicted by commercial seismic lines that show a listric geometry comprising a steep dip of $60^{\circ}$ at the surface, $40^{\circ}$ in the uppermost $4 \mathrm{~km}$, and $\sim 15^{\circ}$ in deeper portions where it reactivates a thrust that originated during the previous compressional phase (Mirabella et al., 2004).

\subsection{The Gualdo Tadino sequence}

The Gualdo Tadino earthquake $\left(M_{w} 5.1\right)$ of April 3, 1998 occurred at the northwestern boundary of the Colfiorito normal-fault system (Amato et al., 1998). The aftershock distribution (section $\mathrm{E}$ in fig. 6) shows a NW-trending and SW-dipping plane confined between 3.5 and $7 \mathrm{~km}$ depth and extending for about $8 \mathrm{~km}$ to the south of Gualdo Tadino; the fault is antithetic to the AtF (Ciaccio et al., 2005). The geometry of the fault plane is consistent with the CMT solution for the mainshock, being located at 6.5 $\mathrm{km}$ depth (C3 in fig. 3; parameters in table I), showing a normal mechanism, and being oriented parallel to the Apenninic Chain. The kinematics of the mainshock and aftershocks reveal a NE-trending extension, in agreement with the regional stress field of the Northern Apennines belt.

\subsection{The Colfiorito sequence}

The Colfiorito sequence began on September 26, 1997 as a repeated sequence of moderate-magnitude earthquakes. This sequence is the most intensively studied sequence of the area because of the huge amount of data recorded by temporary networks and the resulting analysis of several thousand events (sections $\mathrm{F}$ and $\mathrm{G}$ in fig. 6). The strongest earthquake $\left(M_{w}\right.$ 6.0 , September 26,1997 ) is characterized by a normal-faulting mechanism with a NE-SW tension axis (R2 in fig. 4; parameters in table I; $T$ axis azimuth $48^{\circ}$ ), in agreement with the aftershock distribution at depth that identifies the principal fault plane dipping toward the SW (Amato et al., 1998; Ekström et al., 1998; Deschamps et al., 2000; Morelli et al., 2000; Chiaraluce et al., 2003, 2004). The focal mechanisms of the other mainshocks, R1 $\left(M_{w} 5.7\right)$, R4 $\left(M_{w} 5.4\right)$, and R5 $\left(M_{w} 5.6\right)$ are shown in fig. 4. Only the R6 event shows a strike-slip focal mechanism for a shallow depth. Collettini et al. (2005) interpreted this event to represent the reactivation of a pre-existing transfer fault inherited from a previous tectonic regime and linking two adjacent normal-fault segments. Detailed seismological analysis, improved by $3 \mathrm{D}$ locations, reveals a $\sim 40-\mathrm{km}$-long NW-trending structure composed of several low-angle normal-fault segments confined to less than $6 \mathrm{~km}$ depth and with a dip of $40-45^{\circ}$ (Chiarabba and Amato, 2003; Chiaraluce et al., 2004). The relationship between these seismogenic faults and the $\mathrm{AtF}$ is unclear and is a topic of debate; the Colfiorito earthquakes, as in the Gubbio case, ruptured SW-dipping normal faults that are antithetic with respect to the main regional AtF (Boncio and Lavecchia, 2000; Collettini et al., 2000).

\subsection{The Massa Martana sequence}

On May 12, 1997, a $M_{l} 4.5$ earthquake occurred close to Massa Martana, Perugia. This event shows normal faulting and approximately WSW-ENE extension (F10 in fig. 5; Di Luccio et al., 1998). For this sequence, we only know that the aftershocks have magnitudes ranging 
between 1.3 and 3.5 and are located between 2 and $8 \mathrm{~km}$ depth; the aftershock distribution does not define any clear fault plane. It has been proposed (Di Luccio et al., 1998) that this sequence represents the activation of a NW-SE Apenninic fault that is more internal with respect to alignments of the regional Umbria Fault System (section H in fig. 6).

\subsection{The Norcia sequence}

On September 19, 1979, a $M_{w} 5.9$ earthquake occurred near the town of Norcia. The focal solution ( $\mathrm{C} 1$ in fig. 3; parameters in table II) shows a normal fault mechanism and a $T$-axis azimuth of $79^{\circ}$. Deschamps et al. (1984) reported that the aftershock distribution to the south of the study area displays a complex pattern associated with a SW-dipping plane that extends from $2-3 \mathrm{~km}$ to $12-14 \mathrm{~km}$ depth, although the focal depth resolution of the major event is rather poor. Also in this case, the lowangle geometry indicated by the focal mechanism has been associated with the reactivation of a pre-existing low-angle thrust plane, while the sub-vertical distribution of aftershocks has been related to the activation of a steep segment of the Nottoria-Preci normal fault (Boncio and Lavecchia, 2000). In the new relocated sequence (section I, fig. 6), we also observed a complex aftershock distribution with a primary subvertical cluster and a minor vertical cluster located between 7 and $12 \mathrm{~km}$ depth (Chiarabba, pers. comm.).

\section{Discussion and conclusions}

The area investigated in this study is part of the central inner part of the Northern Apennines, which has been characterised by extensional tectonics since the Late Pliocene-Quaternary (Lavecchia et al., 1987; Barchi et al., 1998). We discussed the main seismicity patterns of several seismic sequences by integrating the results of previous studies with newly determined hypocentral locations and focal mechanisms. Our moment tensor solutions and first-motion polarity solutions are combined with a previous dataset, enabling an understanding of the contribution of microseismicity and moderate-magnitude earthquakes to present-day seismicity. The Umbria Region is characterized by diffuse and frequent seismicity that is mostly clustered along a nearby $150-\mathrm{km}$-long alignment in the Apenninic direction. The seismicity mainly occurs on SW-dipping normal faults that strike NNW-SSE. The distribution of seismicity is almost continuous along the Apenninic belt, with the only gap in the instrumental catalogue observed around the Città di Castello area, where historical events are recorded. The new focal mechanisms computed in the present study show mainly normal faulting, consistent with the focal mechanism catalogue of larger earthquakes. Active NE-SW extensional tectonics is observed, consistent with the regional active stress field obtained from large earthquakes and borehole breakouts (Mariucci et al., 1999); this general NE-trending extension is uniform throughout the Apenninic belt (Montone et al., 2004). We observed only a single compressional mechanism, located at $41 \mathrm{~km}$ depth in the eastern area. This subcrustal earthquake is consistent with the results of previous studies (Chiarabba et al., 2005 and references therein) that suggest that the outer belt to the east of the Apenninic Orogen is characterized by thrusts and strike-slip earthquakes, whereas a large area in the west is characterised by extensional mechanisms (Frepoli and Amato, 1997, 2000; Montone et al., 1999).

Almost all of the normal faulting events are concentrated within a shallow block in the upper $12 \mathrm{~km}$, whose base progressively deepens from WSW to ENE, from the inner to the outer side of the Apenninic Chain. The Umbertide sequence is not included in this tectonic framework: it belongs to the sparse, low-magnitude sub-crustal seismicity that affects the entire Northern Apenninic Arc and that is commonly associated with the deep tectonic setting of the Apennines. The earthquakes of the Umbertide sequence likely belong to the arc-like belt of deep-crustal seismicity whose origin is not fully understood, but that almost continuously defines the flexure of the Adria lithosphere beneath the belt (Chiarabba et al., 2005). These earthquakes are commonly considered to pro- 
vide evidence for the active subduction of the Adriatic continental lithosphere beneath the Apennines (Amato and Cimini, 2001). Alternatively, the deep seismicity might be related to the deformation of a west-dipping seismogenic thrust zone within the Adriatic lithosphere rather than subduction (Lavecchia et al., 2003).

The major earthquakes of the area occur on SW-dipping normal faults aligned along a NNW-SSE Apenninic trend on the Umbria Fault System (Barchi, 2002). Focal mechanisms show seismic slip on fault planes dipping at relatively low angles $\left(21\right.$ to $\left.44^{\circ}\right)$. These structures have geometries and kinematics that are consistent with evidence from Quaternary faults mapped at the surface, with the exception of the Gualdo Tadino Fault that is identified as a blind normal fault (Ciaccio et al., 2005).

On the basis of the present results, mainly concerning moderate-magnitude earthquakes, we believe that the regional low-angle east-dipping normal fault named the Altotiberina Fault (AtF) can be considered to represent the base of the seismogenic volume. This is evident from our review of the most recent seismic sequences in this region. The description provided here shows that major earthquakes appear to nucleate on tectonic structures that are antithetic to the AtF, but that are also confined to this regional tectonic unit. Moreover, the AtF separates adjacent zones of contrasting seismicity: high levels of seismic activity to the east in the hanging wall and low levels to the west in THE footwall.

The question of whether the AtF, a very low-angle $\left(\sim 20^{\circ}\right)$ normal fault, is a seismogenic fault is still debated within the scientific community. Analysis of the 2001 Sansepolcro sequence (Braun et al., 2002) raises the possibility that the AtF is able to produce earthquakes, at least along a shallow segment of the fault. The focal mechanism of the Sansepolcro 2001 mainshock shows a gently ENE-dipping and NNW-SSE striking fault plane, which is consistent with the geometry of the AtF. It has been also hypothesized that historical moderatemagnitude earthquakes within the Alta Valtiberina Basin near the AtF surface trace are the expression of seismic activity upon the AtF (Boncio et al., 2000; DISS Working Group, 2005).
Recently, detailed locations of microseismicity between Città di Castello and Gubbio have revealed an alignment of hypocenters at 2 to $\sim 15$ $\mathrm{km}$ depth upon a gently east-dipping fault plane that is possibly continuous with the trajectory of the AtF (Piccinini et al., 2003).

Regarding the NW-SE alignment of active trends along the Apenninic Chain, we would also like to discuss the connection between faults mapped at the surface and faults imaged at depth from patterns of seismicity (geological and seismological faults) associated with some of the main seismogenic faults such as the Gubbio, Colfiorito, and Norcia faults. At the surface, these faults have a relatively steep dip (50$70^{\circ}$ ), but the hypocentral distributions indicate dips of between 20 and $40^{\circ}$. Considering the role of the AtF in determining the lower boundary of the seismicity distribution and the hypothesis of the reactivation of thrust structures during extensional deformation, we clearly consider that inherited structures play a major role in controlling the distribution of seismic ruptures. Confirmation of this role is provided by the fact that in the Colfiorito system, the mainshocks nucleated close to the intersections between normal faults and pre-existing compressional/transpressional structures. During the 1997 sequence, these inherited structures acted as lateral barriers, arresting rupture propagation and delineating the fault segments (Collettini et al., 2005). In addition, almost all of the ruptured fault segments and the analysed instrumental seismicity are confined to within the upper cover of Mesozoic sediments. In this context, the pre-existing thrusts are dissected by present-day extensional tectonics, while discontinuities in the uppermost crust are related to fault segmentation. The depth and thickness of the seismogenic layer is probably controlled by heterogeneous upper-crustal structures inherited from the preceding compressional tectonics.

\section{Acknowledgements}

We would like to thank Massimo Cocco, Lucia Margheriti and Alberto Michelini for constructive reviews of this work. We thank 
Claudio Chiarabba for very helpful comments and suggestions and Lauro Chiaraluce for interesting discussions. We are also grateful to Paola Montone and Massimiliano Barchi for critically reading the manuscript. This work was carried out within the auspices of the project: «Terremoti probabili in Italia tra l'anno $2000 \mathrm{e}$ il 2030: elementi per la definizione di priorità degli interventi di riduzione del rischio sismico» (coordinated by A. Amato - Gruppo Nazionale per la Difesa dai Terremoti).

\section{REFERENCES}

Amato, A. and G.B. Cimini (2001): Deep structure from seismic tomograph, in Anatomy of an Orogen: the Apennines and Adjacent Mediterranean Basins, edited by G.B. VAi and I.P. Martini (Kluwer Academic Publishers) 33-45.

Amato, A., C. Chiarabba and G. Selvaggi (1997): Crustal and deep seismicity in Italy (30 years after), Ann. Geofis., XL (5), 981-993.

Amato, A., R.M. Azzara, C. Chiarabba, G. B. Cimini, M. Cocco, M. Di Bona, L. Margheriti, S. Mazza, F. Mele, G. Selvaggi, A. Basili, E. Boschi, F. Courboulex, A., Deschamps, S. Gaffet, G. Bittarelli, L. Chiaraluce, D. Piccinini and M. Ripepe (1998): The 1997 Umbria-Marche, Italy, earthquake sequence: a first look at the main shocks and aftershocks, Geophys. Res. Lett., 25, 2861-2864.

BARCHI, M.R. (2002): Lithological and structural controls on the seismogenesis of the Umbria Region: observation from seismic reflection profiles, Boll. Soc. Geol. Ital., 1, 855-864.

Barchi, M.R., A. De Feyter, M.B. Magnani, G. Minelli, G. PiALLi and B.M. SOTERA (1998): Extensioanl tectonics in the Northern Apennines (Italy): evidence from the CROP03 deep seismic reflection line, Mem. Soc. Geol. Ital., 52, 527-538.

Barchi, M., F. Galadini, G. Lavecchia, P. Messina, A. Michetti, L., Peruzza, A. Pizzi, E. Tondi and E. VitTORI (2000): Sintesi delle Conoscenze sulle Faglie Attive in Italia Centrale: Parametrizzazione ai Fini della Caratterizzazione della Pericolositá Sismica (GNDT, Gruppo Nazionale per la Difesa dai Terremoti, Roma), pp. 62.

Boncio, P. and G. LAVECCHIA (2000): A structural model for active extension in Central Italy, J. Geodyn., 29, 233-244.

Boncio, M., F. Ponziani, F. Brozzetti, M.R. Barchi, G. LAVECCHIA and G. Pialdi (1998): Seismicity and extensional tectonics in the Northern Umbria-Marche Apennines, Mem. Soc. Geol. Ital., 52, 539-555.

Boncio, P., F. BRozzetTi and G. LAVECCHIA (2000): Architecture and seismotectonics of a regional low angle normal fault zone in central Italy, Tectonics, 19, 10381055.

Braun, T., C. Chiarabba, M.G. Ciaccio, F. Di Luccio and D. PICCININI (2002): Evidenze di attività sismica sulla faglia Altotiberina, in XXI Convegno Nazionale GNGTS, 19-21 Novembre 2002, Roma, Italy, 1, 121.

Castello, B., G. Selvaggi, C. Chiarabba and A. Amato (2005): CSI Catalogo della Sismicità Italiana 19812002, Versione 1.0 (INGV-CNT, Roma), (available on line at http://www.ingv.it/CSI/).

Chiarabba, C. and A. Amato (2003): $V p$ and $V p / V s$ images in the $M_{w} 6.0$ Colfiorito Fault region (Central Italy): a contribution to the understanding of seismotectonic and seismogenic processes, J. Geophys. Res., 108 (B5), 10.1029/2001JB001665.

Chiarabba, C., L. Jovane and R. Di Stefano (2005): A new view of Italian seismicity using 20 years of instrumental recordings, Tectonophysics, 395, 251-268.

Chiaraluce, L., W.L. Ellsworth, C. Chiarabba and M. Cocco (2003): Imaging the complexity of an active complex normal fault system: the 1997 Colfiorito (Central Italy) case study, J. Geophys. Res., 108 (B6), 2294.

Chiaraluce, L., A. Amato, M. Cocco, C. Chiarabba, G. Selvaggi, M. Di Bona, D. Piccinini, A. Deschamps, L. Margheriti, F. Corboulex and M. Ripepe (2004): Complex normal faulting in the Apennines thrust-andfold belt: the 1997 seismic sequence in Central Italy, Bull. Seismol. Soc. Am., 94 (1), 99-116.

Ciaccio, M.G., F. Mirabella, C. Chiarabba, M.R. Barchi and E. STUCCHI (2005): Seismological, geological and geophysical costraints for the Gualdo Tadino Fault, Umbria-Marche Apennines (Central Italy), Tectonophysics, 406 (3-4), 233-247.

Collettini, C., M.R. Barchi, C. Pauselli, C. Federico and G. Pialli (2000): Seismic expression of active extensional faults in Northern Umbria (Central Italy), $J$. Geodyn., 29 (3-5), 309-321.

Collettini, C., M.R Barchi, L. Chiaraluce, F. MirabelLA and S. PUCCI (2003): The Gubbio Fault: can different methods give pictures of the same object?, J. Geodyn., 36 (1-2), 51-66.

Collettini, C., L. Chiaraluce, S. Pucci, M.R. Barchi and M. CocCo (2005): Looking at fault reactivation matching structural geology and seismological data, J. Struct. Geol., 27, 937-942.

CPTI Working Group (2004): Catalogo Parametrico dei Terremoti Italiani, Versione 2004 (CPTI04) (INGV, Bologna), (available on line at http://emidius.mi.ingv.it/CPTI/)

Decandia, F.A., A. Lazzarotto, D. Liotta, L. Cernobori and R. NiCOLICH (1998): The CROP03 traverse; insights on the post-collisional evolution of Northern Apenninesm, Mem. Soc. Geol. Ital., 52, 427-440.

Deschamps, A., G. Innaccone and R. Scarpa (1984): The Umbrian earthquake (Italy) of 19 september 1979, Ann. Geophysicae, 2 (1), 29-36.

Deschamps, A., F. Courboulex, S. Gaffet, A. Lomax, J. VirieuX, A. Amato, R.M. Azzara, B. Castello, C., Chiarabba, G.B. Cimini, M. Cocco, M. Di Bona, L. Margheriti, F. Mele, G. Selvaggi, L. Chiaraluce, D. PICCININI and M. RIPEPE (2000): Spatio-temporal distribution of seismic activity during the Umbria-Marche crisis, 1997, J. Seismol., 4 (4), 377-386.

Di Luccio, F., A. Amato, R.M. Azzara, A. Basili, A. DelLadio, M. Di Bona, A. Gorini, F.P. Lucente, S. MarCucci, L. Margheriti, G. Milana, F. Ponziani, G. SELVAGgi and E. ZAmbONELLI (1998): La sequenza sismica del maggio 1997 a Massa Martana (PG), in Atti 
XIX Convegno Nazionale GNGTS, 7-9 Novembre 1998, Roma, Italy, 1, 65.

DISS WORKING GROUP (2005): Database of Individual Seismogenic Sources (DISS), Version 3.0.1: a Compilation of Potential Sources for Earthquakes Larger than M 5.5 in Italy and Surrounding Areas (available on line at http://www.ingv.it/banchedati/banche.html).

DzIEWONSKI, A.M., G. EKSTRÖM and N.N. MATERnOvSKAYA (2000): Centroid-moment tensor solutions for October December 1999, Phys. Earth Planet. Int., 121, 205-221.

Elter, P., G. Giglia, M. Tongiorgi and L. Trevisan (1975): Tensional and compressional areas in the recent (Tortonian to present) evolution of the Northern Apennines, Eos Trans. Am. Geophys. Un., 56 (3), 166.

Ekström, G., A. Morelli, E. Boschi and A.M. DziewonsKI (1998): Moment tensor analysis of the Central Italy earthquake sequence of September-October 1997, Geophys. Res. Lett., 25, 1971-1974.

Frepoli, A. and A. Amato (1997): Contemporaneous extension and compression in the Northern Apennines from earthquake fault plane solutions, Geophys. J. Int., 129, 368-388.

Frepoli, A. and A. Amato (2000): Stress tensor orientation in peninsular Italy from background seismicity, Tectonophysics, 317, 109-124.

Haessler, H., R. Gaulon, L. Rivera, R. Console, M. Frogneux, G. Gasparini, L. Martel, G. Patau, M. SiCiliano and A. Cisternas (1988): The Perugia (Italy) earthquake of 29 april 1984: a microearthquake survey, Boll. Soc. Geol. Am., 78 (6), 1948-1964.

KLEIN, F.W. (1989): User's guide to Hypoinverse, a program for VAX computers to solve for earthquake locations and magnitudes, U.S. Geol. Surv. Open File Rep. 89-314, pp. 49.

Lavecchia, G., G. Minelli and G. Pialli (1987): The Umbria-Marches arcuate fold-belt, Tectonophysics, 146, 125-137.

Lavecchia, G., P. Boncio, N. Creati and F. Brozzetti (2003): Some aspects of the Italian geology not fitting with a subduction scenario, J. Virtual Explorer, 10, 1-42.

Lucente, F.P., C. Chiarabba, G.B. Cimini and D. Giardini (1999): Tomographic constraints on the geodynamic evolution of the Italian region, J. Geophys. Res., 104 (B9), 20307-20327.

Mariucci, M.T., A. Amato and P. Montone (1999): Recent tectonic evolution and present stress in the Northern Apennines (Italy), Tectonics, 18 (1), 108-118.

Mirabella, F., M.G. Ciaccio, M.R. Barchi and S. MerliNI (2004): The Gubbio Fault (Central Italy): geometry, displacement distribution and tectonic evolution, $J$. Struct. Geol., 26, 2233-2249.

Montone, P., A. Amato and S. Pondrelli (1999): Active stress map of Italy, J. Geophys. Res., 104 (B11), 2559525610.

Montone, P., M.T. Mariucci, S. Pondrelli and A. Amato (2004): An improved stress map for Italy and surrounding regions (Central Mediterranean), J. Geophys. Res., 109 (B10410), doi: 10.1029/2003JB002703.

Morelli, A., G. Ekström and M. Olivieri (2000): Source properties of the 1997/98 Central Italy earthquake sequence from inversion of long-period and broad-band seismograms, J. Seismol., 4 (4), 365-375.

Nostro, C., L. Chiaraluce, M. Cocco, D. Baumont and O. SCOTTI (2005): Coulomb stress changes caused by repeated normal faulting earthquakes during the $1997 \mathrm{Um}-$ bria-Marche (Central Italy) seismic sequence, J. Geophys. Res., 110 (B5), B05S20, 10.1029/2004JB003386.

Piccinini, D., M. Cattaneo, C. Chiarabba, L. Chiaraluce, M. De Martin, M. Di Bona, M. Moretti, G. Selvaggi, P. Augliera, D. Spallarossa, G. Ferretti, A. Michelini, A. Govoni, P. Di Bartolomeo, M. RoMANELLI and J. FABBRI (2003): A microseismic study in a low seismicity area of Italy: the Città di Castello 2000-2001 experiment, Ann. Geophysics, 46 (6), 13151324.

Pondrelli, S., A. Morelli, G. Ekström, S. Mazza, E. Boschi and A.M. DzIEwonski (2002): EuropeanMediterranean regional centroid-moment tensors: 1997-2000, Phys. Earth Planet. Int., 130, 71-101.

Pondrelli, S., A. Morelli and G. Ekström (2004): European-Mediterranean regional centroid-moment tensor catalog: solutions for years 2001 and 2002, Phys. Earth Planet Inter, 145, 127-147.

REAsEnberG, P. and D. OPPENHEIMER (1985): FPFIT, FPPLOT and FPPAGE: FORTRAN computer programs for calculating and displying earthquake fault-plane solutions, U.S. Geol. Surv. Open-File Rep. 85-739.

SelvagGi, G. and A. Amato (1992): Subcrustal earthquakes in the Northern Apennines (Italy): evidence for a still active subduction?, Geophys. Res. Lett., 19, 21272130.

ZoBACK, M.L. (1992): First- and second-order patterns of stress in the lithosphere: the World Stress Map Project, J. Geophys. Res., 97 (B8), 11703-11728.

(received January 12, 2006; accepted July 29, 2006) 